\title{
THE CONNECTION BETWEEN POLYSOMNOGRAPHY RESULTS, EPWORTH SCORES AND DRUG-INDUCED SLEEP ENDOSCOPY FINDINGS IN PATIENTS WITH OSAS
}

\author{
OUAS HASTALARINDA ILAÇLA INDÜKLENMIŞ UYKU ENDOSKOPISI BULGULARININ \\ POLISOMNOGRAFI VE EPWORTH SKALASI SONUÇLARI ILE ILIŞKISI
}

\author{
Mustafa Sıtkı GÖZELER ${ }^{1}$ (D), Yusufhan SUOĞLU² (D) \\ ${ }^{1}$ Ataturk University, Faculty of Medicine, Department of Otorhinolaryngology, Erzurum, Turkey \\ ${ }^{2}$ Acıbadem Hospital, Department of Otorhinolaryngology, Istanbul, Turkey
}

ORCID IDs of the authors: M.S.G. 0000-0002-9716-9579; Y.S. 0000-0002-4547-5320

Cite this article as: Gozeler MS, Suoglu Y. The connection between polysomnography results, Epworth scores and drug-induced sleep endoscopy findings in patients with OSAS. J Ist Faculty Med 2020;83(3):209-14. doi: 10.26650/IUITFD.2019.0041

\begin{abstract}
Objective: To determine the usefulness of drug-induced sleep endoscopy (DISE) and evaluate correlations between DISE findings, polysomnography and Epworth sleepiness scale values.

Material and Method: Included in this study are patients with major OSAS symptoms and apnea-hypopnea index (AHI) values between 5 and 30 who were scheduled for soft palate surgery. The patients were sedated with propofol $(0.25 \mathrm{cc} / \mathrm{kg})$ in the operating room for examination of obstructive regions. Anatomical structures affected by obstruction were observed with flexible endoscopy. The images from this examination were analyzed with Ulead video study. Patients with soft palate pathologies were operated and the endoscopic examination repeated postoperatively. Changes in pre- and post-operative obstruction areas were compared with changes in pre- and post-op PSG and Epworth sleepiness scale values.
\end{abstract}

Results: Changes in retropalatal area values were correlated with changes in $\mathrm{AHI}$ values. The most important factor affecting this correlation was the formation of base of tongue pathology, despite being absent preoperatively. We also determined the correlation between patients' Epworth scores, $\mathrm{AHI}$ and retropalatal area. Changes in the retropalatal area following OSAS surgery were correlated with changes in $\mathrm{AHI}$ and Epworth scores.

Conclusion: DISE is an effective diagnostic technique in OSAS with advantages such as a low radiation risk, cost effectiveness and precise findings.

Keywords: Drug-induced sleep endoscopy, Obstructive sleep apnea, Epworth sleepiness scale

\section{ÖZET}

Amaç: Bu çalışmada tıkayıcı uyku apnesi sendromlu (TUAS) hastalarda ilaçla indüklenmiş uyku endoskopisinin (iiUE) önemini ortaya koymak ve iiUE bulguları ile polisomnografi ve Epworth uyku skalası sonuçları arasındaki ilişkiyi araştırmayı amaçladık.

Gereç ve Yöntem: Çalışma prospektif olarak planlandı. Çalışmaya major TUAS semptomlarına sahip, apne-hipopne indeksi (AHI) 5 ile 30 arasında olan ve yumuşak damak cerrahisi adayı olan hastalar dahil edildi. Hastalar tıkayıcı lezyonun muayenesi için ameliyathane şartlarında propofol ile $(0,25 \mathrm{cc} / \mathrm{kg})$ sedatize edildi. Tıkanma sonucu etkilenen anatomik yapılar fleksible endoskop ile araştırıldı. Bu muayene sonucu elde edilen görüntü Ulead video study programı ile analiz edildi. Yumuşak damak patolojisi olan hastalar opere edilerek operayon sonrası endoskopi işlemi tekrarlandı. Operasyon öncesi ve sonrası tıkanma alanlarındaki değişim ile polisomnografi ve Epworth skalasındaki değişimler karşılaştırıldı.

Bulgular: Retropalatal alandaki değişim ile AHI değişimi korele idi. Bu korelasyonu en fazla etkileyen faktör operasyon öncesi olmayan dil kökü patolojisinin ortaya çıkması idi. Ayrıca Epworth skorları ile AHI ve retropalatal alan arasında da korelasyon tespit ettik. TUAS cerrahisi sonrası retropalatal alandaki değişim AHI ve Epworth skorundaki değişim ile korele olarak tespit edildi.

Sonuç: iiUE, TUAS hastalarında düşük radyasyon riski, ucuz olması ve değerli verileri sayesinde etkili bir tanı tekniğidir.

Anahtar Kelimeler: ilaç ile indüklenmiş uyku endoskopisi, tıkayıcı uyku apnesi, Epworth uyku skalası

'The study was based on Mustafa Sitki Gozeler's specialty thesis under the supervision of Yusufhan Suoglu and was published as a poster presentation in Otolaryngology-Head and Neck Surgery in August 2010.

Corresponding author/iletişim kurulacak yazar: msgozeler@gmail.com

Submitted/Başvuru: 23.05.2019 • Revision Requested/Revizyon Talebi: 18.09.2019•

Last Revision Received/Son Revizyon: 19.09.2019 • Accepted/Kabul: 24.09.2019 • Published Online/Online Yayın: 21.10.2019

(C) Telif Hakkı $2020 \mathrm{~J}$ Ist Faculty Med - Makale metnine jmed.istanbul.edu.tr web sayfasından ulaşılabilir.

CCopyright 2020 by J Ist Faculty Med - Available online at jmed.istanbul.edu.tr 


\section{INTRODUCTION}

Sleep is an essential component of a healthy life. Although sleep is primarily a cerebral function, there has been increased understanding of its effects on respiration in recent decades (1). Sleep-related breathing disorders include various diseases that carry the risk of mortality and morbidity. The most common sleep-related breathing disorder is obstructive sleep apnea syndrome (OSAS).

OSAS is a widespread condition affecting $4 \%$ of males and $2 \%$ of females (2). The most common symptoms are snoring, witnessed apnea, and excessive daytime sleepiness caused by transient upper airway collapse. The most useful tool in the diagnosis of OSAS and in treatment planning is polysomnography (PSG). The apnea-hypoxia index $(\mathrm{AHI})$, a parameter of polysomnographic evaluation, is regarded as indicating the severity of the disease. The Epworth sleepiness scale is a simple questionnaire applied to investigate eight common situations in daily life (3).

Drug-induced sleep endoscopy (DISE) has become widely used in the diagnosis of OSAS and treatment planning over the last two decades. DISE is an endoscopic examination that can be performed during sleep to visualize possible upper airway collapses and that was recommended by Croft and Pringle in 1990 (4).

The therapeutic modality of preference in the treatment of OSAS is continuous positive airway pressure (CPAP). However, various difficulties in the use of CPAP encourage patients to investigate alternative treatments (5). The most important of these are upper airway surgery, mandibular advancement, and weight loss.

The purpose of this study was to reveal the relations between DISE findings, PSG and Epworth sleepiness scale scores, and postoperative OSAS surgery outcomes in patients scheduled for upper airway surgery due to OSAS.

\section{MATERIALS AND METHODS}

Approval was granted for this prospective study by the ethical committee of Istanbul University, Faculty of Medicine. Patients scheduled for soft palate surgery due to OSAS symptoms with AHI scores between 5 and 30 were included in the study. Consent was obtained from all patients before the study began.

Physical examination with detailed history was performed in all cases. Subjects with previous history of upper airway surgery, with chronic obstructive pulmonary disease, with cardiovascular disease and contraindicated for sedation, or with anemia or hypothyroidism were excluded from the study. Body mass index (BMI) and Mallampati scores at physical examination were also recorded.

The Epworth sleepiness scale was applied to all patients to assess the degree of daytime sleepiness, one of the major symptoms of OSAS. This questionnaire is based on scoring eight different situations widely observed in daily life. Total scores higher than 10 were regarded as significant in terms of OSAS.

All patients underwent polysomnography preoperatively and 6 months postoperatively, using a 15-channel Medilog Replay (Oxford Medical Ltd., Clearwater, FL, USA) device. Full-night parameters were collected from an electroencephalogram, electrooculogram, submental and anterior tibialis electromyogram, and electrocardiogram. AHI, desaturation index and minimum oxygen desaturation values recorded from the PSG findings were used in the study.

DISE was performed with a surgeon and an anesthetist and with the patient in the supine position in all cases. Patients received $0.25 \mathrm{mg}$ atropine by the intramuscular route before the procedure in order to reduce upper airway secretions. Two puffs of lidocaine $10 \mathrm{~mm} /$ puff (xylocaine spray $10 \%$, ASTRA) were administered to both nostrils to reduce the potential effects of the flexible nasopharyngoscope and thus reduce arousals to a minimum. Patients were monitored throughout the procedure, and cardiac rhythms and oxygen saturations were kept under observation. Propofol (200 mg / 20 ml flask; ABBOTT) was used to provide adequate sedation. A bolus injection of propofol $1.5-2.5 \mathrm{mg} / \mathrm{kg}$ was administered, and bolus was repeated at $25-50 \mathrm{mg}$ as required. When a sufficient level of sleep had been established, a $3.5 \mathrm{~mm}$ flexible nasopharyngoscope (Karl Storz 11101 RP, Germany) was inserted through the nasal cavity. The nasal cavity, nasopharynx, the base of the tongue, and the larynx were then evaluated. DISE was applied with the assistance of a monitor, and the findings were recorded onto computer for analysis. The images from this examination were analyzed using Ulead video study (Corel Corporation, Canada). On the basis of the findings, appropriate surgery was decided and performed in cases with isolated soft palate pathology. All DISE examinations, calculations and surgeries were performed by the same surgeon. Patients with pathologies associated with the base of the tongue or the hypopharynx were excluded from the study. DISE was repeated in the sixth month after surgery. Changes in pre- and post-operative obstruction areas were compared with changes in pre- and post-operative PSG and Epworth sleepiness scale scores. Pre- and post-operative $\mathrm{AHI}$, desaturation index, minimal oxygen saturation, Epworth scores and retro palatal region values were investigated.

\section{Statistical analysis}

SPSS 12.0 software was used for the statistical analysis of all data. The Shapiro-Wilk test was used to determined distribution of data. Student's t-test was employed for two-group comparisons of normally distributed data, and 
the Mann Whitney $U$ test was used when distribution was not normal. The chi-square test was used for the analysis of categorical data. Correlations were determined using Pearson's test. P-values $<0.05$ were regarded as statistically significant for all tests.

\section{RESULTS}

Forty-one patients aged 35-68 were included in the study, 30 men and 11 women. Mean preoperative AHI was 20.0 \pm 5.6 . No significant difference was determined between men and women in terms of preoperative $\mathrm{AHI}$ $(p=0.806)$. Mean preoperative BMI was $29.8 \pm 2.6$, and no statistically significant difference was observed between the gender $(p=0.624)$. Measurements performed with DISE revealed a mean preoperative retropalatal area of $2.7 \pm 1.1$.

The mean postoperative $\mathrm{AHI}$ was $16.4 \pm 6.3$, and the decrease in $\mathrm{AHI}$ values was statistically significant $(p=0.009)$. The mean postoperative retropalatal region was $6.5 \pm 4.8$, representing a significant increase $(p<0.001)$ (Table 1$)$.

Table 1: Pre-postoperative values

\begin{tabular}{lccc}
\hline & Preoperative & Postoperative & $\mathbf{p}$ \\
AHI & $20 \pm 5.6$ & $16.4 \pm 6.3$ & $0.009^{*}$ \\
Area & $2.7 \pm 1.1$ & $6.5 \pm 4.8$ & $0.000^{*}$ \\
MOS & $90.3 \pm 3.8$ & $91.4 \pm 3.5$ & 0.180 \\
\hline
\end{tabular}

*Statistically significant

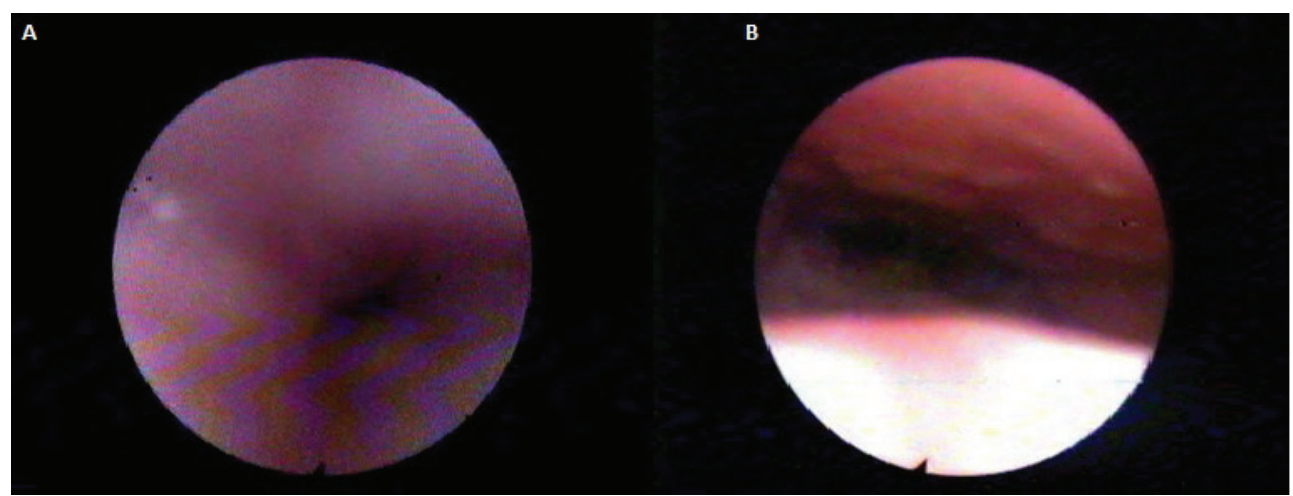

Figure 1: Enlargement of retropalatal region in a patient after surgery. A. Preoperative B. Postoperative.
The imaging of the retropalatal region of a patient before and after the operation is given in Figure 1.

No statistically significant difference was observed between pre- and postoperative Epworth scores $(p=0.137)$, but the operation-related change in Epworth scores was positively correlated with change in $\mathrm{AHI}(r=0.524$, $(p=0.000)$ and negatively correlated with change in the retropalatal region $(r=-0.311, p=0.047)$.

Significant reverse correlation was determined between operation-related change in $\mathrm{AHI}$ and change in the retropalatal region $(p=0.03)$. These results have shown that significant enlargement in retropalatal areas postoperatively resulted in significant decreases in $\mathrm{AHI}$ values and Epworth scores. Correlations are given in Table 2.

While patients with isolated soft palate pathology were included in the study, those with pathologies of the base of the tongue were excluded. Follow-ups of patients undergoing soft palate surgery revealed enlargement of the retropalatal areas, but base of the tongue pathology was observed in 11 of the cases. Collapse in the base of the tongue which was not present at preoperative examination was one important factor affecting operative success. Postoperative $\mathrm{AHI}$ in patients with postoperatively occurred collapse in the base of the tongue was $18.7 \pm 5.6$, and the change in AHI before-after surgery was determined as $2.8 \pm 2.4$. These values in subjects without

Table 2: Correlations between changes in $\mathrm{AHI}$, area and Epworth scores

\begin{tabular}{|c|c|c|c|}
\hline & Changes in $\mathrm{AHI}$ & Changes in area & Changes in Epworth \\
\hline \multirow[t]{2}{*}{ Changes in $\mathrm{AHI}$} & & $r=-0.323$ & $r=0.524$ \\
\hline & & $p=0.039 *$ & $p=0.000^{\star}$ \\
\hline \multirow[t]{2}{*}{ Changes in area } & $r=-0.323$ & & $r=-0.311$ \\
\hline & $p=0.039 *$ & & $p=0.04$ \\
\hline \multirow[t]{2}{*}{ Changes in Epworth } & $r=0.524$ & $r=-0.311$ & \\
\hline & $p=0.000 *$ & $p=0.04^{*}$ & \\
\hline
\end{tabular}

*Statistically significant 


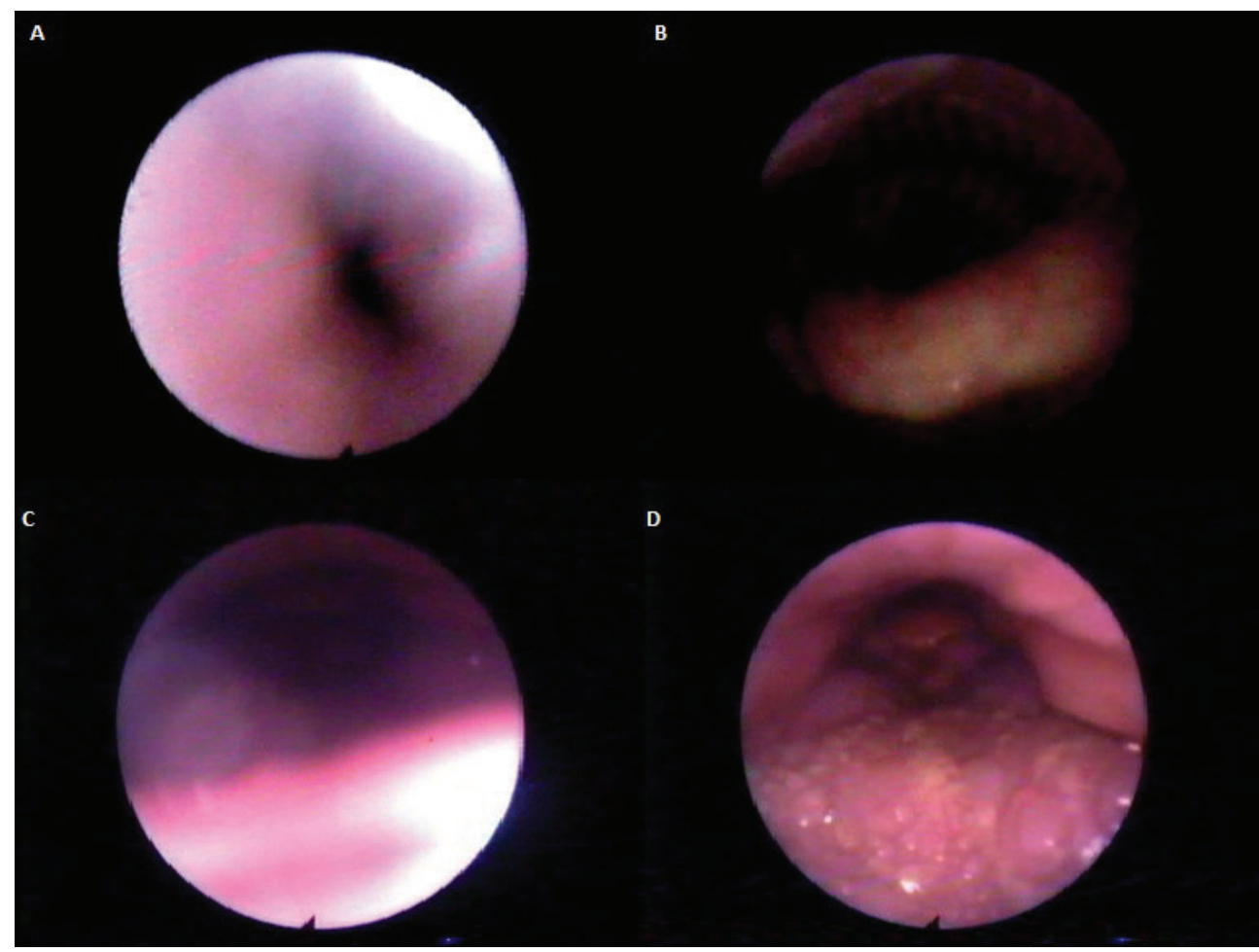

Figure 2: Preoperative and postoperative images of the retropalatal and base of tongue regions of a patient. A. Preoperatively, the retropalatal region is narrowed. B. Preoperatively, the base of tongue is normal. C. After operation there is an enlargement at the retropalatal region. D. After operation a collapse in the base of tongue occurred.

base of the tongue pathology were $15.5 \pm 6.5$ and 3.7 \pm 3.6 , respectively. While there was no difference between preoperative retropalatal area and $\mathrm{AHI}$ values of the patients in the two groups, retropalatal area $(p=0.006)$ and postoperative change in retropalatal area $(p=0.002)$ were significantly greater in patients with base of tongue collapse, although postoperative $\mathrm{AHI}$ values were higher in patients with no base of the tongue pathology. Figure 2 demonsrates a patient without preoperative collapse in the base of tongue, but a collapse occurred after the operation.

\section{DISCUSSION}

The standard test in the diagnosis of OSAS is PSG, yet this is not sufficient to determine the diseased region. The areas most commonly affected in patients with OSAS are the soft palate, the lateral pharyngeal wall, and the base of the tongue. Locating the affected region is very important in terms of guiding treatment and in the selection of patients for surgery. Various tools and tests have been used for this purpose in the diagnosis of OSAS. One of the most commonly employed tests is Müller's maneuver, which helps to assess the dynamics, site, and severity of airway collapse. Some authors have suggested that it may also be useful as a predictor of surgical success (6), although its usefulness in surgical planning is still controversial. Indeed, in their study of the effectiveness of Müller's maneuver, snoring endoscopy and DISE, Lovato et al. reported that the maneuver is less effective than DISE in determining upper airway collapse patterns (7). Similarly, Zerpa et al. described Müller's maneuver as less effective than DISE in locating the obstruction (8).

Another method used to locate the obstruction in OSAS is cephalometric analysis. This involves the measurement of cephalometric distance, angle, area, and volume between distinct reference points in bony and soft tissues on a film. It is not only used for diagnostic purposes, but also to evaluate bony and soft tissues in the preoperative period in patients scheduled for surgical therapy for OSAS. Sakat et al. employed cephalometric measurements with multislice CT in patients with OSAS and reported that cephalometry yielded significant results in terms of locating the area of obstruction in OSAS (9). However, since all these examinations are performed with the patient awake, they may still be inadequate in terms of showing the area that is actually affected during sleep. For that purpose, in 1990 Croft and Pringle developed a method for observing the upper airways during sleep (4). DISE, an endoscopic method performed to visualize collapse in the upper airway during drug-induced sleep, is reliable, dynamic, effective 
and simple to perform. Operations performed with indications based on DISE findings are more effective. Better results have been reported to be capable of being achieved with upper airway surgery, particularly under conditions of grade 3-4 tonsil hypertrophy and soft palate collapse, during surgery (10). Belgü et al. compared AHI, Epworth score and DISE findings and reported that AHI scores are not effective in determining the site of collapse in the upper airways outside the base of the tongue, for which reason sleep endoscopy must be performed on all patients for whom surgical decisions are to be made (11). In our study, we compared PSG findings with Epworth score and DISE findings. Our findings also showed correlation between patients' Epworth scores, $\mathrm{AHI}$ and retropalatal areas, and that changes in retropalatal area after OSAS surgery were correlated with changes in $\mathrm{AHI}$ and Epworth scores.

Viana et al. reviewed various studies investigating the effectiveness of DISE use in locating the area of obstruction in OSAS. They concluded that DISE use is particularly effective in revealing problems in the larynx and hypophar$y n x$ region (12). Salamanca et al. investigated the use of DISE in 614 patients, the highest number to date in the literature, and reported obstruction in a single region in $61.3 \%$ of patients with $\mathrm{AHI}<15$, that this single region was the oropharynx in $92.6 \%$ of cases, and that obstruction was present in more than one region in $28.2 \%$ of patients. They also reported a single obstruction in $46.5 \%$ of patients with $\mathrm{AHI}>15$, that the oropharynx represented this single region at a level of $95 \%$, and that obstruction was observed in more than one region in $53.5 \%$ of cases. In addition, they showed that the larynx also contributed to the pathology in $12.5 \%$ of patients with $\mathrm{AHI}>15$ (13).

The most significant limitation of our study was the low number of cases. Another important limitation was that a particular patient population was investigated, with only OSAS patients with isolated soft palate pathology being included. However, pathologies in other areas of the upper respiratory tract are also associated with OSAS. Third, since patients were only followed-up for one year postoperatively, long-term follow-up data are not available.

\section{CONCLUSION}

DISE is an effective diagnostic technique in OSAS with advantages such as cost effectiveness and precise findings. We think that DISE in patients scheduled for surgery due to OSAS will contribute to operation selection.

Ethics Committee Approval: Ethics committee approval was received for this study from the Istanbul University, Faculty of Medicine Ethics Committee.

Informed Consent: Written consent was obtained from the participants.
Peer Review: Externally peer-reviewed.

Author Contributions: Conception/Design of Study- M.S.G., Y.S.; Data Acquisition- M.S.G., Y.S.; Data Analysis/InterpretationM.S.G., Y.S.; Drafting Manuscript- M.S.G., Y.S.; Critical Revision of Manuscript- M.S.G., Y.S.; Final Approval and AccountabilityM.S.G., Y.S.; Technical or Material Support- M.S.G., Y.S.; Supervision- M.S.G., Y.S.

Conflict of Interest: Authors declared no conflict of interest.

Financial Disclosure: Authors declared no financial support.

Etik Komite Onayı: Bu çalışma için etik komite onayı İstanbul Üniversitesi Tıp Fakültesi Etik Kurulundan alınmıştır.

Bilgilendirilmiş Onam: Katılımcılardan bilgilendirilmiş onam alınmıştır.

Hakem Değerlendirmesi: Dış bağımsız.

Yazar Katkıları: Çalışma Konsepti/Tasarım- M.S.G., Y.S.; Veri Toplama- M.S.G., Y.S.; Veri Analizi/Yorumlama- M.S.G., Y.S.; Yazı Taslağı- M.S.G., Y.S.; İçeriğin Eleştirel İncelemesi- M.S.G., Y.S.; Son Onay ve Sorumluluk- M.S.G., Y.S.; Malzeme ve Teknik Destek- M.S.G., Y.S; Süpervizyon- M.S.G., Y.S.

Çıkar Çatışması: Yazarlar çıkar çatışması beyan etmemişlerdir.

Finansal Destek: Yazarlar finansal destek beyan etmemişlerdir.

\section{REFERENCES}

1. Kokturk O. Breathing disturbances in sleep: history, definition, spectrum and dimension of the disease (in Turkish). Tüberküloz ve Toraks 1998;46:187-92.

2. Amos JM, Durr ML, Nardone HC, Baldassari CM, Duggins A, Ishman SL. Systematic review of drug-induced sleep endoscopy scoring systems. Otolaryngol Head Neck Surg 2018;158(2):240-8. [CrossRef]

3. Johns MW. A new method for measuring daytime sleepiness: the Epworth sleepiness scale. Sleep 1991;14:540-5. [CrossRef]

4. Croft CB, Pringle M. Sleep nasendoscopy: a technique of assessment in snoring and obstructive sleep apnoea. Clin Otolaryngol 1990;16:504-9. [CrossRef]

5. Storesund A, Johansson A, Bjorvatn B, Lehmann S. Oral appliance treatment outcome can be predicted by continuous positive airway pressure in moderate to severe obstructive sleep apnea. Sleep Breath 2018;22(2):385-92. [CrossRef]

6. Ko MT, Su CY. Computer-assisted quantitative evaluation of obstructive sleep apnea using digitalized endoscopic imaging with Muller maneuver. Laryngoscope 2008;118:90914. [CrossRef]

7. Lovato A, Kotecha B, Vianello A, Giacomelli L, Staffieri A, Marchese-Ragona R. Nasal and oral snoring endoscopy: novel and promising diagnostic tools in OSAS patients. Eur Arch Otorhinolaryngol 2015;272(7):1793-9. [CrossRef]

8. Zerpa Zerpa V, Carrasco Llatas M, Agostini Porras G, Dalmau Galofre J. Drug-induced sedation endoscopy versus clinical exploration for the diagnosis of severe upper airway obstruction in OSAS patients. Sleep Breath 2015;19(4):1367-72. [CrossRef] 
PSG results and DISE findings in OSAS

İstanbul Tıp Fakültesi Dergisi • J Ist Faculty Med 2020;83(3):209-14

9. Sakat MS, Sütbeyaz Y, Yüceler Z, Kantarci M, Kilic K, Kurt S. Cephalometric Measurements with Multislice Computed Tomography in Patients with Obstructive Sleep Apnea Syndrome. J Craniofac Surg 2016;27(1):82-6. [CrossRef]

10. Wang Y, Sun C, Cui X, Guo Y, Wang $Q$, Liang $H$. The role of drug-induced sleep endoscopy: predicting and guiding upper airway surgery for adult OSA patients. Sleep Breath 2018;22(4):925-31. [CrossRef]

11. Belgü $A U$, Erdoğan $B$, San T, Gürkan E. The relationship between AHI, Epworth scores and sleep endoscopy in patients with OSAS. Eur Arch Otorhinolaryngol 2015;272(1):241-5. [CrossRef]
12. Viana Ada C Jr, Thuler LC, Araújo-Melo MH. Drug-induced sleep endoscopy in the identification of obstruction sites in patients with obstructive sleep apnea: a systematic review. Braz J Otorhinolaryngol 2015;81(4):439-46. [CrossRef]

13. Salamanca F, Costantini F, Bianchi A, Amaina T, Colombo E, Zibordi F. Identification of obstructive sites and patterns in obstructive sleep apnea syndrome by sleep endoscopy in 614 patients. Acta Otorhinolaryngol Ital 2013;33:261-6. 